\title{
THE RECOVERY OF MITOTIC DISTURBANCES IN THE ROOT SYSTEMS OF GAMMA-RAY IRRADIATED PEAS
}

\author{
E. I. Kivi and J. T. H. Barkman \\ Plant Breeding Institute of Hankkija, \\ Tammisto, Helsingin pit. Finland
}

|Received April 24, 1967

Irradiating a multicellular organ, like the embryo of a seed, produces a large number of cells with different stages and types of physiological and cytological changes. The viability and vitality of these cells can vary greatly, and among them a selection takes place from the beginning of the first mitoses. The worst damaged cells withdraw and the average state of further cell divisions is always healthier than that of the primary mitoses (GAUL 1957a, 1957b, GELIN 1953, GusTAFSSON 1937, voN Rosen 1954, SAX 1940). The disturbances of the embryonic cells might manifest themselves in the slow growth of seedlings, the smaller size and irregular shape of embryonic leaves and also in cessation of further growth when the cells of the plumula should begin to differentiate into cell systems and organs (cf. KIvi 1962).

The frequency of mitotic disturbances and their elimination during the very first mitoses of irradiated seeds has been described in several papers (GAUL 1957a, 1957b, GELIN 1953, 1956). In this investigation attempts have been made to follow the trend and effectiveness of the recovery of meristematic tissues somewhat further, to the end of the third week of growth, and various efforts have been made to follow the changes taking place in a certain number of seedlings individuals.

Material and methods. The dormant seeds (with a moisture content of 8.8 per cent) of the Dutch green pea (Pisum sativum) variety Rondo were irradiated in March 1964. The source of the gamma radiation was the $\mathrm{Co}^{60}$ installation of the Institute of Radiochemistry, University of Helsinki; the dose was $7000 \mathrm{rads}$ at a rate of $3000 \mathrm{rads} / \mathrm{min}$. After the irradiation treatment the seeds were stored in room conditions until the growth experiments which took place during March-August 1964. The growing of the seeds was begun in ordinary 

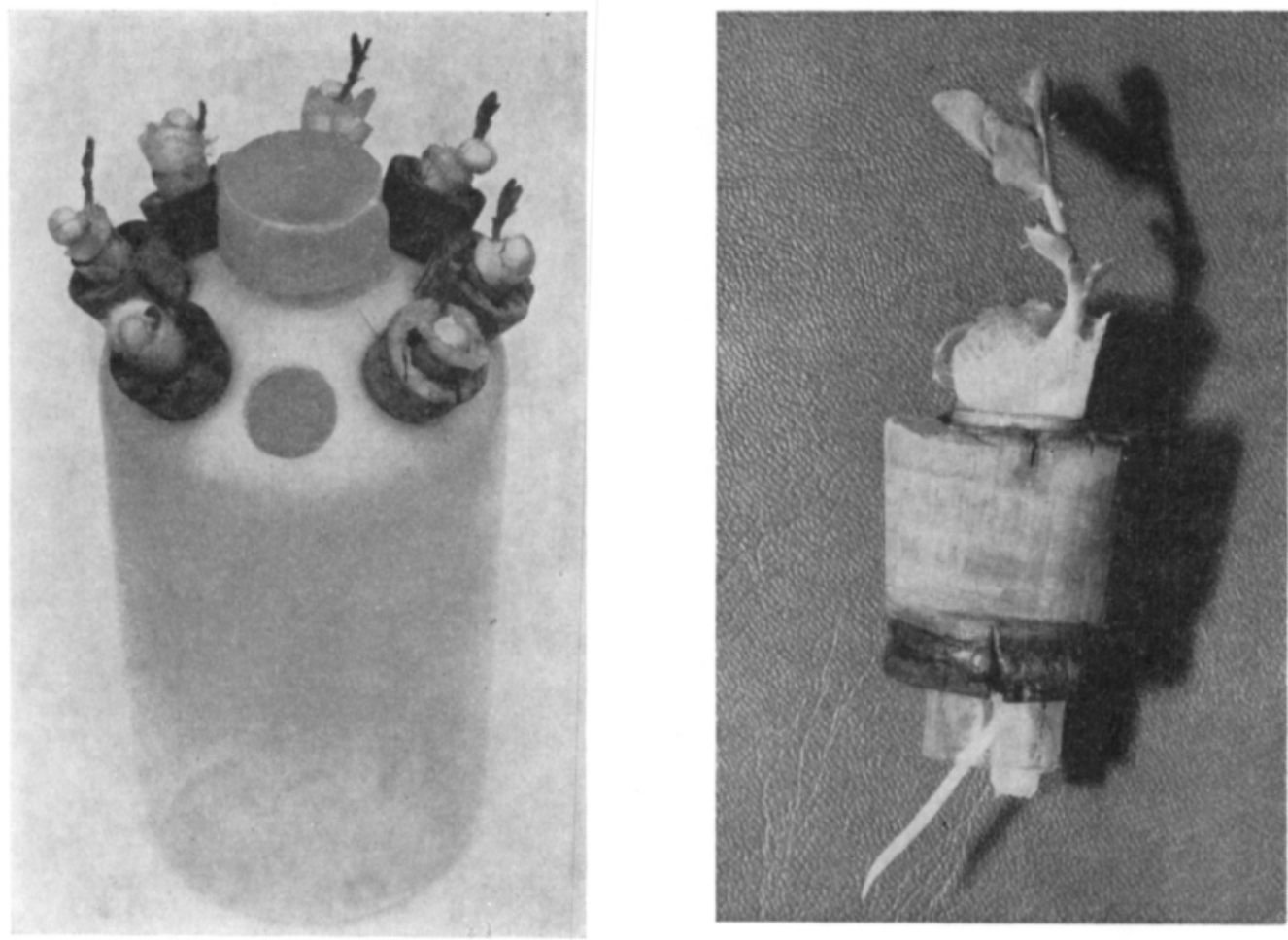

Fig. 1. The growing bottle with seedlings of Rondo peas approx. 10 days old (left) and details in the placing of one seedling (right).

emergency testing boxes and the first mitotes were analysed 3 to 5 days after the beginning of the growth experiment. The specimens for later investigations of mitoses were transferred on the 5th day of growing into growth bottles made of plastic and specially converted for this treatment. The bottles were approx. 2000 $\mathrm{cm}^{3}$ in volume with 8 holes bored along the upper edge of each bottle (Fig. 1). Artificial light was used during the growing, in other respects the experiments were performed under uncontrolled laboratory room conditions. In the bottles a commercial nutritive medium ("Hormos»-solution) was used. The control plants were handled in the same way.

Feulgen staining and the procedures by BLIXT (1958) were employed. The squashes were made with a special foot press. The frequency of mitotic disturbances was determined on the basis of fragments and/or bridges during the stages from metaphase to early telophase. All root tips in which at least 20 divisions were countable have been included in this study material. During the first mitoses, from the 3rd to the 5th day, one root tip of each plant was analysed, in later preparations, if available, two tips were taken of root branches already developed. The numbers of individuals and divisions investigated on different days are seen in Table 1.

Results. The frequency of mitotic disturbances decreased with great rapidity after the first mitoses. This trend reached its maximum during the 3rd and 5th days (Table 1, Fig. 2). Twelve days after the growing had begun, no statisti- 
cally significant differences were to be seen between irradiated and control material, even though the decreasing trend of disturbances could be noticed in treated material between the 12th and 19th days.

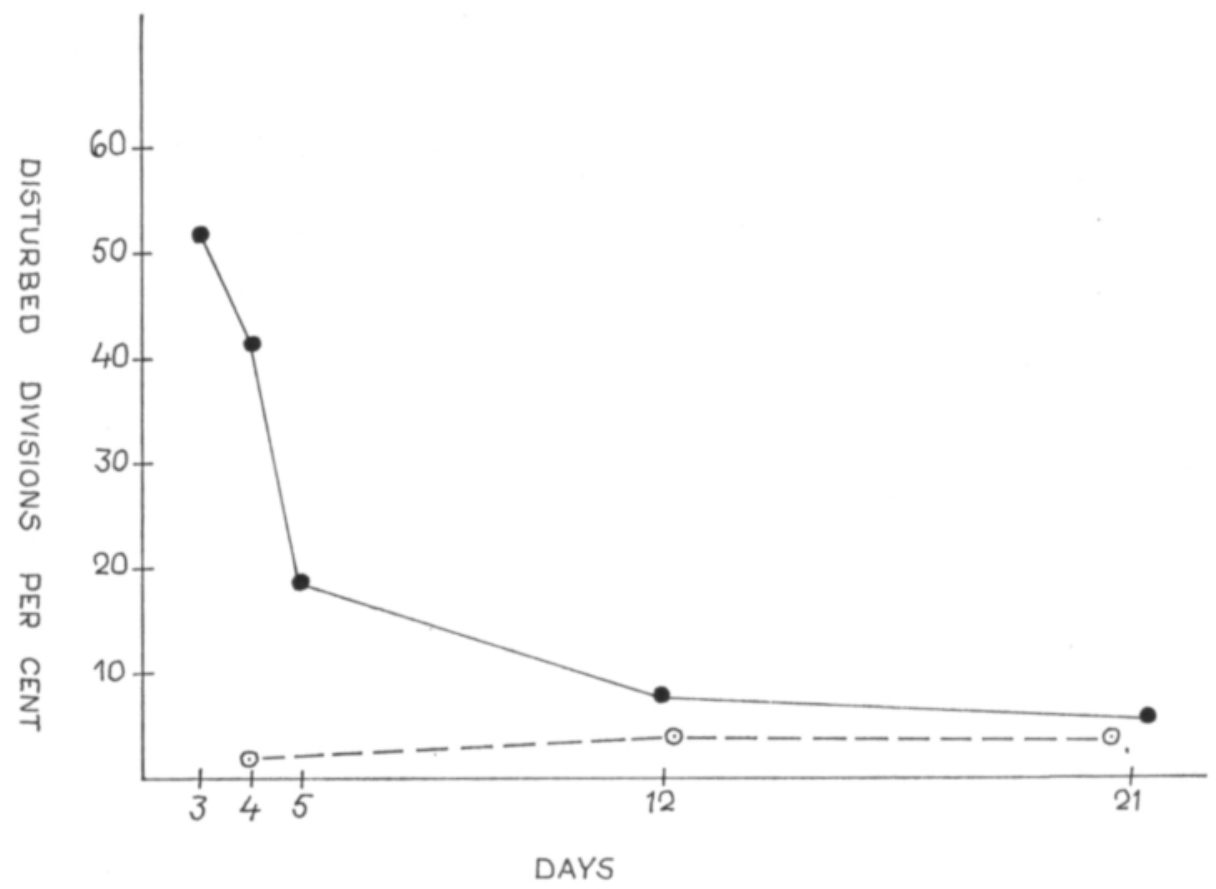

Fig. 2. The frequency of mitotic disturbances in root tips. (For explanations, see Table 1.)

A very wide variability in the degree of damage was visible in different seeds and the frequencies of disturbances in the 11 individuals analysed 5 days after growth was begun (cf. Table 1) varied from 4 to 52 per cent, with an average of 18.9 per cent.

Table 1. The material investigated on different days after the beginning of growth and the frequency of chromosomal irregularities in irradiated and control plants.

\begin{tabular}{|c|c|c|c|c|c|c|c|c|c|c|}
\hline \multicolumn{11}{|c|}{ Days after the beginning of growth } \\
\hline \multirow{2}{*}{$\begin{array}{c}\text { No. of } \\
\text { analysed }\end{array}$} & \multicolumn{2}{|r|}{3} & \multicolumn{2}{|c|}{4} & \multicolumn{2}{|c|}{5} & \multicolumn{2}{|c|}{$12 *)$} & \multicolumn{2}{|c|}{$\left.21^{* *}\right)$} \\
\hline & Irr. & Contr. & Irr. & Contr. & Irr. & Contr. & Irr. & Contr. & Irr. & Contr. \\
\hline plants & 10 & - & 34 & 12 & 11 & - & 27 & 33 & 17 & 12 \\
\hline root tips & 10 & - & 34 & 12 & 11 & - & 39 & 53 & 32 & 30 \\
\hline divisions & 250 & - & 785 & 240 & 275 & - & 875 & 1250 & 705 & 670 \\
\hline $\begin{array}{l}\text { Disturbed } \\
\text { divisions } \\
\text { per cent }\end{array}$ & 52.4 & & 42.0 & $-* *-$ & 18.9 & -**- & 7.6 & & 5.4 & \\
\hline $\begin{array}{l}\text { (with the } \\
t \text { - test } \\
\text { significance) }\end{array}$ & & & $* *$ & -2.1 & & & & 4.6 & & 3.4 \\
\hline
\end{tabular}




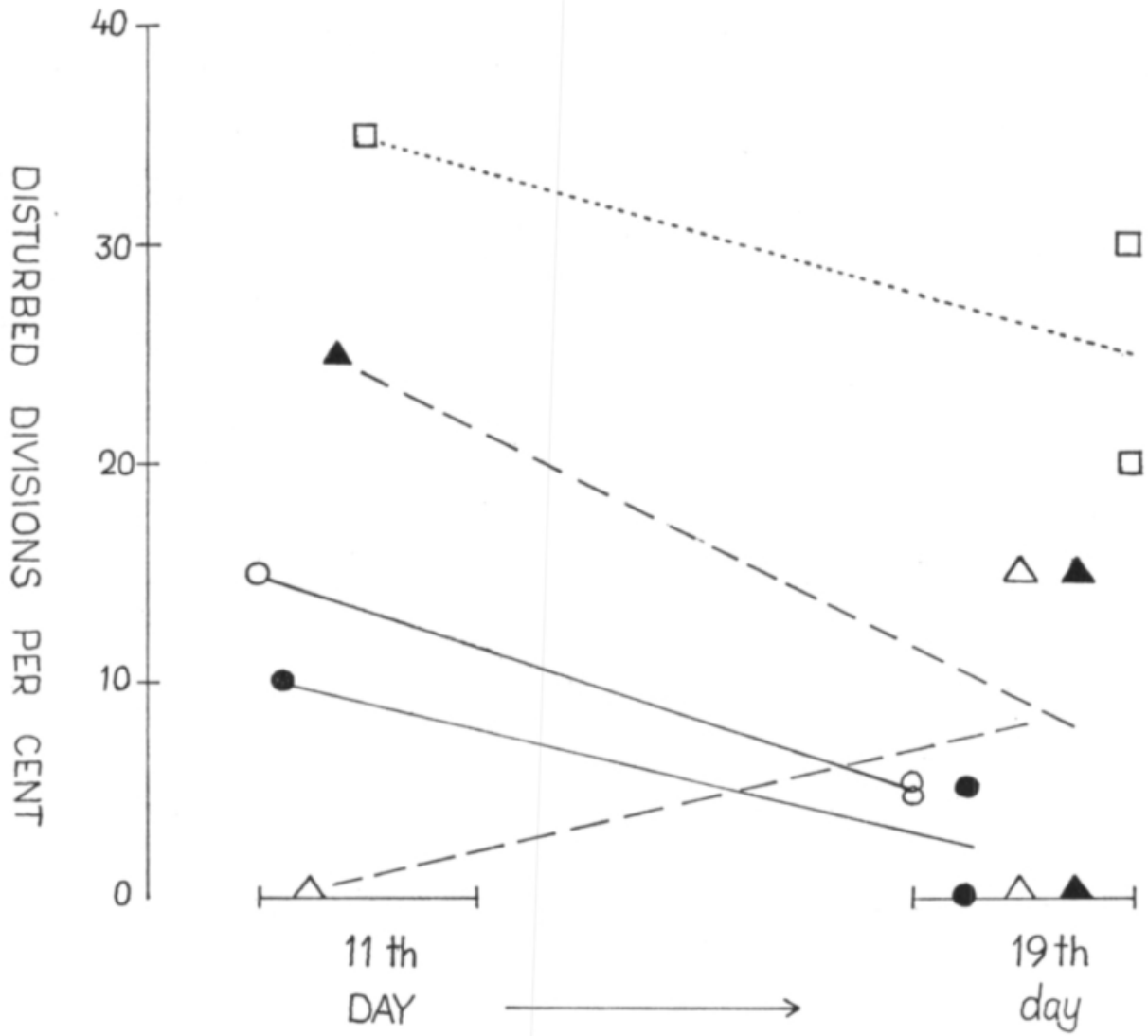

Fig. 3. The frequency of mitotic disturbances in five individuals analysed on the 11th (main root tip) and the 19th day (tips of two branches).

Normally, the frequency of disturbances in the root tips of each individual decreased during the period, as can be seen in Fig. 3 which shows the results from the analyses of 5 individual plants. In four individuals the frequency of disturbances in two root tips analysed on the 19th day were lower than in the tip of the main root prepared on the 11th day of growing. In one case, however, extensive damage occurred in one of the tips on the 19th day, whereas the analysis made on the 11th day had given a completely normal picture of the mitoses.

During the period of storage of the seed samples prior to their growing tests, a slight decrease in the frequency of mitotic disturbances occurred; thus, in March the frequency of those investigated on the 5th day of growing was 46 per cent and in August 37 per cent. However, based on this material the difference had no statistical significance.

Discussion. Before any change of hereditary material induced by a mutagenic agent can manifest itself in the $\mathrm{M}_{2}$-generation it must be able to pass certain effective prevention systems during the development of the irradiated plant. These selectional barriers may be divided into two groups defined as "the sieve of mitosis" and that of meiosis. The first mentioned selection system is active, 
during the whole vegetative development until the appearance of the mother cells of the gametes, when the "sieve of meiosis" become active. However, the "sieve of mitosis» is most effective immediately after the beginning of the growth of the irradiated seeds, as can be seen in the results of this investigation, which are in complete agreement with earlier studies e.g. by SAX (1941) on Allium and by GAuL $(1957 \mathrm{a}, \mathrm{b})$ on barley. According to the last-mentioned paper, in mitoses approx. two days after the beginning of growth, the frequency of disturbances was 22.2 per cent but in those of the 3rd day only 6.2 per cent, showing a difference of 16 percentage units. The seeds of barley were treated with 4000 rads and the bridges in anaphase and early telophase were counted. In the present study the number of disturbed divisions decreased between the 4th and 5th day by 23 percentage units. As Gaul (1957a) has stated, the high frequency of disturbances in the root tip cells which begin to grow first, might be connected with the pre-mitotic stage of those already in the dormant embryo. These cells are, thus, more susceptible to radiation than those which are in an interphase, and progress more slowly to the divisional stages when the seed begins to grow. There are also differences apparent in this study between the radiation resistance in seeds of the same seed lot, which was noted earlier e.g. by GELIN (1953) on barley.

The very variable and non-oriented picture of the reactions of different embryos and the cells of one embryo to irradiation is highly dependent on the multicellular construction of embryonic tissues. JACOBSEN (1966) has recently shown that several tissues occur in barley embryo each leading separately to spike while in the occurrence of mutations after mutagenic treatments, these tissues are highly independent of each other.

The recovery of mitoses thus rapidly leads to a relatively well balanced situation as regards the regularity of mitotic divisions. This does not mean that the labile effects of mutation treatments were completely passed off but in the meiotic divisions numerous chromosomal disturbances will be seen and in a portion of these a certain response to the mitotic damage can be noticed (GELIN 1953). These disturbances belong to the msieve of meiosis» and they bring about a sterility of the gametes (Krvi 1962) and a reduced viability of the tsygotes in the $\mathrm{M}_{2}$-generation when irradiated parents are crossed with each other (WELlensieK 1959).

\section{$S u m m a r y$.}

Dormant seeds of a green pea variety Rondo were irradiated with 7000 rads of gamma rays from $\mathrm{Co}^{60}$ source. The frequency of mitotic disturbances in root tip cells was analysed during the first three weeks of growth.

In agreement with earlier works a rapid decrease of frequency was observed: during the 4 th and 5th days of growing the proportion of disturbances was reduced from 42 to 19 per cent and it came close to the level of the control material during the third week of growth.

The discussion briefly examines the importance of the msieve of mitosis» and its relation to the ssieve of meiosis» in eliminating the changes of hereditary material during the development of the $\mathrm{M}_{1}$-generation. 


\title{
REFERENCES
}

Blixt, S. 1958. Cytology of Pisum. I. Methodogical investigation. Agri Hort. Gen. 16: 66 - 77.

GAUL, H: 1957 a. Zur Frage der ontogenetischen Elimination mutierter Zellen nach Röntgenbestrahlung von Samen. Naturwiss. 44: 566.

- 1957 b. Uber die Bedeutung der Fixierungszeit bei der zytologischen Untersuchung von Sprosspitzen nach Röntgenbestrahlung. Ibid. 44: 403.

GeLIN, O. E. V. 1953. Mitotische Störungsfrequenzen in Röntgenbestrahlter Gerste. Agri Hort. Gen. 11: $66-81$.

- 1956. The meiotic response to the mitotic disturbances in X-rayed barley. Ibid. 14: $107-126$.

Gustafsson, A. 1937. The different stability of chromosomes and the nature of mitosis. Hereditas 12: $281-335$.

JACOBSEN, P. 1966. Demarcation of mutant-carrying regions in barley plants after ethylmethanesulfonate seed treatment. Radiation Botany 6: $313-328$.

Krvı, E. I. 1962. On sterility and other injuries in dioecious Melandrium irradiated with X-rays and Gamma rays. Ann. Acad. Sci. Fenn. Ser. A, IV Biol. 56: $1-96$.

Rosen, G. voN. 1954. Radiomimetic reactivity arising after treatment employing elements of the periodic system, organic compounds, acids, electric current in an electrolyte, temperature shocks and ionizing radiation. Comparison with the mutagen effect. Material: Pisum, Allium, Beta and Vicia. Socker 8: $157-273$.

SAX, K. 1941. The behaviour of X-ray induced chromosomal aberrations in Allium root tip cells. Genetics 26: $418-415$.

Wellensiek, S. J. 1959. Neutronic mutations in peas. Euphytica 8: $209-215$.

\section{MITOOSIVAURIOITTEN KARSIUTUMINEN GAMMA-SÄTEILYTETYN HERNEEN JUURISTOSSA}

\author{
E. I. Krvi ja J. T. H. BARKMAN \\ Hankkijan kasvinjalostuslaitos \\ Tammisto, Helsingin pitäjä
}

Rondo-herneen kuivia siemeniä säteilytettiin $7000 \mathrm{r}: \mathrm{n}$ annoksella Helsingin yliopiston radiokemian laitoksen $\mathrm{Co}^{60}$-lähdettä käyttäen. Siemenet idätettiin muovipulloissa, jolloin juurten kärjistä voitiin tehdä mitoosivalmisteita noin kolmen viikon ajan. Ensimmäisissä mitooseissa oli vaurioitumisprosentti yli 50, mutta se aleni hyvin nopeasti niin, että 4. ja 5. vuorokauden välillä tapahtui 23 prosenttiyksikön vähentyminen vaurioituneitten mitoosijakojen määrässä. Noin 12 päivää idätyksen alkamisesta tehdyissă valmisteissa oli jonkin verran suurempi vaurioitumisprosentti kuin vertailuaineistossa, joka ei missåän vaiheessa ylittånyt 5 prosenttia, mutta ero ei enää ollut tilastollisesti luotettava.

Mitoosivaurioitten jyrkkä väheneminen ensimmäisten vuorokausien aikana on yhdenmukainen muitten tutkijain toisilla objekteilla suorittamien tutkimustulosten kanssa. "Mitoosiseula", joka karsii pois huomattavan osan säteilyn aikaansaamista sytologisista muutoksista on siis tehokkaimmillaan yksilökehityksen alkuvaiheissa. Tilanteen tasapainottuminen, mikä tämän tutkimuksen tulosten mukaan saavutettiin, mitoosivaurioitten perusteella pääteltynä, $2-3$ viikon kuluttua itämisen alkamisesta, ei kuitenkaan merkitse sitä, että säteilyn aikaansaamat vauriot olisivat tyystin eliminoituneet, sillä gameettien yhteydessä esiintyy jälleen voimakkaita kromosomihäiriöitä. Myös ne karsivat pois suuren mäărän syntyneitä perinnöllisen informaation muutoksia ja muodostavat siten mmeioosiseulans. Mutaation on tullakseen ilmi $\mathrm{M}_{2}$-polvessa pystyttävä siis läpäisemään säteilytetyn sukupolven yksilökehityksen mittaan tehokkaita biologisia torjuntajärjestelmiä, jotka nimenomaan ensimmäisten mitoosien aikana perustuvat elinkyvyltään eriarvoisten solujen keskinäiseen kilpailuun. 